\title{
Multi-approach analysis to assess diet of harbour porpoises Phocoena phocoena in the southern North Sea
}

\author{
Céline Mahfouz $^{1, *}$, Tarik Meziane ${ }^{2}$, Françoise Henry ${ }^{3,4,5}$, Carine Abi-Ghanem ${ }^{1,6}$, \\ Jérôme Spitz ${ }^{7}$, Thierry Jauniaux ${ }^{8,9}$, Thibaut Bouveroux ${ }^{10,11}$, Gaby Khalaf ${ }^{1}$, Rachid Amara ${ }^{3,4,5}$ \\ ${ }^{1}$ CNRS, National Centre for Marine Sciences, PO Box 534, Batroun, Lebanon \\ ${ }^{2}$ Unité Mixte de Recherche Biologie des organismes et écosystèmes aquatiques (BOREA UMR 7208), Sorbonne Universités, \\ Muséum national d'Histoire naturelle, Université Pierre et Marie Curie, Université de Caen Basse-Normandie, CNRS, IRD, CP53, \\ 61 rue Buffon, 75005 Paris, France \\ ${ }^{3}$ University of Lille Nord de France, 59650 Villeneuve-d'Ascq, France \\ ${ }^{4}$ Laboratoire d'Océanologie et de Géosciences, Université du Littoral, 62930 Wimereux, France \\ ${ }^{5}$ CNRS, UMR 8187, 62930 Wimereux, France \\ ${ }^{6}$ Faculté des Sciences 3, Université Libanaise, Tripoli, Lebanon \\ ${ }^{7}$ Observatoire PELAGIS - Système d'Observation pour la Conservation des Mammifères et Oiseaux Marins, UMS 3462, \\ CNRS/Université de La Rochelle, 17000 La Rochelle, France \\ ${ }^{8}$ Department of Pathology, Fundamental and Applied Research for Animals and Health (FARAH), Faculty of Veterinary Medicine, \\ B43, Liège University, 4000 Liège, Belgium \\ ${ }^{9}$ Operational Directorate Natural Environment, Royal Belgian Institute of National Sciences, Gulledelle 100, 1200 Brussels, Belgium \\ ${ }^{10}$ Nelson Mandela Metropolitan University, Coastal and Marine Research Institute, PO Box 77000, Port Elizabeth, South Africa \\ ${ }^{11}$ Observatoire pour la Conservation et l'Etude des Animaux et Milieux Marins - OCEAMM, 59123 Zuydcoote, France
}

\begin{abstract}
Over the past decade, the distribution of harbour porpoises Phocoena phocoena has undergone a southward shift in the North Sea, which has led to an increase in the number of stranded porpoises in its southern part. Since the changes in distribution and relative abundance of porpoises may be linked to the changes in prey availability, the aim of the present work was to investigate whether any changes in the feeding habits of harbour porpoises along the North Sea occurred in the past decade. The diet of harbour porpoises stranded along the southern North Sea (northern France and Belgian coast) was assessed through 3 complementary methods: stomach content analysis, stable isotopes (carbon and nitrogen) analysis determined from muscle samples, and fatty acids analysis determined from blubber samples. Fatty acid patterns and stable isotope values from 52 porpoises were compared to 14 potential prey species collected from the southern North Sea. Our results showed that the diet of porpoises along the southern North Sea comprises fish species that are among the most abundant and widely distributed in the area, except for the sardine Sardina pilchardus that appeared to be a new potential prey. Moreover, our results suggested that the decline in sandeel (Ammodytidae) in the northern parts of the North Sea along with the re-invasion of the southern North Sea by sardine species might affect the distribution of harbour porpoises.
\end{abstract}

KEY WORDS: Harbour porpoises · North Sea $\cdot$ Distribution $\cdot$ Foraging ecology $\cdot$ Stomach contents Stable isotopes $\cdot$ Fatty acids

Resale or republication not permitted without written consent of the publisher-

\section{INTRODUCTION}

Harbour porpoises Phocoena phocoena are the most common cetacean species in the North Sea
(Hammond et al. 2013). A comparison between the results of the 2 major abundance and distribution surveys in European waters revealed a major shift in the distribution of harbour porpoises from the northern 
parts of the North Sea to its southeastern parts rather than a population increase in the English Channel (Hammond et al. 2002, 2013). Also, a clear increase in the number of stranded animals has been observed along the southern North Sea, including the Netherlands, Belgium and northern France, since the beginning of the 21st century (Jauniaux et al. 2008, Haelters \& Camphuysen 2009).

In order to meet specific energy requirements, harbour porpoise foraging strategies and diet are shaped by the quality of their prey (Spitz et al. 2012). The distribution of this predator is expected to follow the distribution of its main prey species (Santos et al. 2004). Therefore, changes in prey abundance due to temporal variation, fishing or other anthropogenic impacts may negatively affect porpoise survival by reducing the availability of prey or by inducing its dispersal (Lassalle et al. 2012). In fact, changes in the distribution and relative abundance of porpoises in the southern North Sea over the last few decades have been linked to changes in prey availability (Camphuysen 2004, MacLeod et al. 2007, Hammond et al. 2013). Accordingly, studying the feeding ecology of harbour porpoises serves to investigate their feeding strategy, predator-prey relationships, and responses to changes in food web dynamics, climate change or fishery interactions (Haelters \& Camphuysen 2009, Herr et al. 2009). In turn, this information can be used to devise or improve appropriate conservation management for harbour porpoises.

Several techniques are widely used to study the feeding ecology of marine mammals, including stomach content analysis (e.g. Santos \& Pierce 2003), bulk stable isotopes analysis (e.g. Hobson et al. 1994) and fatty acid (FA) analysis (e.g. Iverson et al. 2004, Budge et al. 2006). These diet estimation methods have their assumptions and limitations. They differ in the level of information they give on diet (i.e. quantitative versus qualitative and species versus general trophic level) and they also differ in time scale (i.e. more recent diet versus longer-term diet) (reviewed in Bowen \& Iverson 2013). To our knowledge, only a few studies have combined the 3 methods to assess the foraging ecology of marine mammals (Hooker et al. 2001, Jansen 2013). Through using all of the above methods, we can gain a more comprehensive insight on predator diet and foraging strategies. The objectives of this paper are (1) to determine the feeding ecology of harbour porpoises along the southern North Sea by using stomach content, stable isotopes and FA analyses, and (2) to investigate changes in the feeding ecology of harbour porpoises by comparing the present results to previous diet studies.

\section{MATERIALS AND METHODS}

\author{
Sampling and data collection
}

Muscle and blubber samples were collected from 52 stranded harbour porpoises in the southern North Sea along French and Belgian coasts between 2010 and 2013, with 14, 9, 15 and 14 individuals collected in 2010, 2011, 2012 and 2013, respectively. There were 15 juvenile females, 27 juvenile males, 7 adult females and 3 adult males. Fourteen porpoises were sampled for stomach content analysis: 4 stomachs from 2012 and 10 from 2013. This sampling included 10 juvenile males, 2 adult females, 1 adult male and 1 undetermined porpoise. Muscles, blubbers and stomachs were stored at $-20^{\circ} \mathrm{C}$ prior to analysis. All animals were freshly dead and sampled up to $48 \mathrm{~h}$ after death (Jauniaux et al. 2002). Post-mortem investigations were performed according to the protocol from Kuiken \& Hartmann (1993) and Jauniaux et al. (2002). Morphometric data such as sex and length were collected, and, according to the length of the animal, age groups were determined (see Table 1). Porpoises with lengths 91-135 cm were considered juveniles and >135 cm were considered adults (Jauniaux et al. 2002).

Fourteen potential prey species were collected along the southern North Sea in June, October and November 2012. Prey species were previously identified as potential prey for harbour porpoises in the study area (Santos et al. 2004, Haelters et al. 2012). Prey samples were stored at $-20^{\circ} \mathrm{C}$ prior to analysis and selected in order to cover the size-classes found in the stomach contents of the harbour porpoises.

\section{Stomach content analyses}

Porpoise stomachs were weighed then rinsed through running water and contents were emptied in a sieve with a mesh size of $0.2 \mathrm{~mm}$. Otoliths and fish vertebrae were stored dry, whereas whole or partly digested prey items and cephalopod beaks were stored in $70 \%$ ethanol. All remains were counted, measured and identified to the lowest taxonomic level using our reference collection of specimens and published data from Leopold et al. (2001). Otoliths were identified, sorted into left and right, and measured (right otolith width and length) using a video system fitted to a compound microscope and the image analysis system TNPC 5.0. Fish weight and length estimates were calculated from the measured length and width of otoliths using regressions from 
Leopold et al. (2001). No corrections were made for loss or reduction of size of prey remains due to digestion. Extremely eroded or broken otoliths were removed prior to counting and measuring.

Three indices were used to estimate the prey importance in the diet of harbour porpoises:

Percentage frequency of occurrence $(\% O)$ :

$$
\% O_{i}=\left(n_{i} / n\right) \times 100
$$

where $n_{i}$ is the number of stomachs where the particular prey species was found and $n$ is the total number of non-empty stomachs;

Percentage by number $(\% N)$ :

$$
\% N_{i}=\left(N_{i} / N\right) \times 100
$$

where $N_{i}$ is the number of the particular prey species found and $N$ is the total number of prey found;

Percentage by mass $(\% W)$ :

$$
\% W_{i}=\left(W_{i} / W\right) \times 100
$$

where $w_{i}$ is the total weight of the particular prey species and $w$ is the total weight of all prey species.

The $\% N$ and the $\% W$ were calculated for each prey type in each individual stomach and then averaged across all stomachs in order to avoid the influence of outliers.

\section{Stable isotopes analysis}

Stable isotope ratios $\left({ }^{15} \mathrm{~N} /{ }^{14} \mathrm{~N}\right.$ and $\left.{ }^{13} \mathrm{C} /{ }^{12} \mathrm{C}\right)$ were determined in the dorsal muscle of harbour porpoises and fish, except for gobies (Gobiidae) where the whole body was ground. Samples were freeze-dried for $48 \mathrm{~h}$ then ground into fine powder. An aliquot of approximately $100 \mathrm{mg}$ from each sample was mixed with $4 \mathrm{ml}$ of cyclohexane for lipid extraction, since lipids are highly depleted in ${ }^{13} \mathrm{C}$ compared to other tissue components (Tieszen et al. 1983). Samples were agitated for $1 \mathrm{~h}$ at $800 \mathrm{rpm}$ then centrifuged for 5 min at $4000 \times g$. The upper solution containing the lipids was removed and the samples were dried in an oven at $50^{\circ} \mathrm{C}$ for $48 \mathrm{~h}$. Subsamples of dried and lipidfree muscle powder $(0.35 \pm 0.05 \mathrm{mg})$ were weighed into tin cups. Stable isotope measurements were performed with an elemental analyser coupled to an isotope ratio mass spectrometer (DELTA V ADVANTAGE Isotope Ratio MS, Thermo Scientific). The stable carbon isotope composition of an aliquot of the freeze-dried and powdered sample is referred to as the 'bulk' stable carbon isotope composition in this article.

Stable isotope abundances are expressed in delta notation in parts per thousand (\%o) following the equation:

$$
\delta X=\left(\frac{R_{\text {Sample }}}{R_{\text {Standard }}}-1\right) \times 1000
$$

where $X$ represents ${ }^{13} \mathrm{C}$ or ${ }^{15} \mathrm{~N}$ and $\mathrm{R}_{\text {sample }}$ is the ${ }^{13} \mathrm{C} /{ }^{12} \mathrm{C}$ or ${ }^{15} \mathrm{~N} /{ }^{14} \mathrm{~N}$ isotopic ratio of the sample. Ratios are expressed relative to the international standards $\left(\mathrm{R}_{\text {standard }}\right)$ VPDB and atmospheric $\mathrm{N}_{2}$ for ${ }^{13} \mathrm{C}$ and ${ }^{15} \mathrm{~N}$ measurements, respectively. Replicate measurements of internal laboratory standards (acetanilide) during each series of measurement indicated errors less than $0.15 \%$ and $0.20 \%$ for carbon and nitrogen, respectively.

\section{FA composition}

FA compositions were determined from the inner blubber layer of harbour porpoises and the muscle of prey species. Relatively high levels of dietary FA are usually found in the inner layer of harbour porpoise blubber, suggesting that it is more metabolically active than the outer layer (Koopman et al. 1996). Before FAs extraction, an internal standard (23:0) was added to approximately $50 \mathrm{mg}$ of fresh blubber from harbour porpoise or freeze-dried muscle from prey (Bligh \& Dyer 1959, modified as in Meziane et al. 2007). Samples were subject to ultrasonication for 20 min with distilled water: $\mathrm{CHCl}_{3}: \mathrm{MeOH}(1: 1: 2$, $\mathrm{v}: \mathrm{v}: \mathrm{v})$. Afterwards, the addition of a distilled water: $\mathrm{CHCl}_{3}$ mixture (1:1, v:v) and centrifugation (5 min, $1100 \times g$ ) of the mixture formed a 2-layer system. The lower $\mathrm{CHCl}_{3}$ layer containing the lipids was retained. This step was repeated one more time with $\mathrm{CHCl}_{3}$ $(2 \mathrm{ml})$. The residue obtained from the consecutive extractions was concentrated under an $\mathrm{N}_{2}$ flow, then saponified in a mixture of $2 \mathrm{~mol} \mathrm{NaOH}: \mathrm{MeOH}(1: 2$, $\mathrm{v}: \mathrm{v})$ and heated for $90 \mathrm{~min}$ at $100^{\circ} \mathrm{C}$. In order to obtain the total lipids as methyl esters, saponification and methylation were conducted according to Meziane \& Tsuchiya (2002). For identification, FA methyl esters (FAMEs) were separated and quantified by gas chromatography equipped with a flame ionization detector (GC; Varian CP-3800). The GC was fitted with a Supelco OMEGAWAX 320 column $(30 \mathrm{~m}, 0.32 \mathrm{~mm}$ ID, $0.25 \mu \mathrm{m}$ film thickness). Helium was the carrier gas. The sample $(1 \mu \mathrm{l})$ was injected at $60^{\circ} \mathrm{C}$ and the temperature was raised to $150^{\circ} \mathrm{C}$ at $40^{\circ} \mathrm{C} \mathrm{min}^{-1}$, then ramped up to $240^{\circ} \mathrm{C}$ at $3^{\circ} \mathrm{C} \mathrm{min}^{-1}$ and kept there for 
14 min. Peaks were identified by comparing their retention times with those of authentic standards (Supelco $^{\mathrm{TM}} 37$, PUFA Mix - No 1 Marine Source and Bacterial mix). For some samples, peaks of FAs were confirmed with GC-mass spectrometry (GC-MS; ThermoFinnigan TRACE DSQ). Standard nomenclature is used for the identified FAs $(x: y \omega z)$, where $x$ is the number of carbon atoms, $y$ is the number of double bonds and $z$ is the position of the ultimate double bond from the terminal methyl.

According to Schomburg (1987), the concentration of each FA $\left(C_{\mathrm{FA}}, \mathrm{mg}\right)$ was calculated as:

$$
C_{\mathrm{FA}}=\frac{A_{\mathrm{S}}}{A_{\mathrm{IS}}} \times \frac{C_{\mathrm{IS}}}{W_{\mathrm{S}}}
$$

where $A_{\mathrm{S}}$ is the peak area of the FA, $A_{\mathrm{IS}}$ is the peak area of the internal standard, $C_{\mathrm{IS}}$ is the concentration of the internal standard $(\mathrm{mg})$, and $W_{\mathrm{S}}$ is the dry weight $(g)$ of the sample for prey species and fresh weight for the blubber of porpoises.

\section{Data analysis}

Data analysis of stable isotopes was performed using XLSTAT - Pro 2013 (Addinsoft). The level of significance was set at $\alpha=0.05$. We used ANOVA followed by post hoc multiple comparison tests to compare $\delta^{15} \mathrm{~N}$ and $\delta^{13} \mathrm{C}$ values in muscle between age classes (juveniles, adult females and adult males) and among years of stranding (2010-2013). Age class and sex comparisons within each year could not be made due to small sample sizes. Thus, individuals were pooled within each year to investigate interannual variation. We used a Kruskal-Wallis test to compare $\delta^{15} \mathrm{~N}$ and $\delta^{13} \mathrm{C}$ values in the muscle of prey species chosen for SIAR (see next paragraph) followed by a post hoc test for multiple comparisons to check for pairwise differences.

The stable isotope mixing model SIAR (Stable Isotope Analysis in R; R Development Core Team 2010) was used to estimate the relative contribution of each prey species in the diet of harbour porpoises stranded in the southern North Sea. The main prey species contributing to the total diet of porpoises as determined by weight from stomach content analyses and as identified in previous studies were considered as potential sources: gobies (Gobiidae), sandeels (Ammodytidae), different species of Gadidae (whiting Merlangius merlangus and pouting Trisopterus spp.) and some clupeids (herring Clupea harengus, sprat Sprattus sprattus and sardine Sardina pilchardus) (Santos et al. 2004, Haelters et al. 2012). We ran 2 models: Model 1 based on the trophic enrichment factors (TEFs) for captive harp seals as given by Hobson et al. (1996) (1.3 \pm 0.1 [SD]\% and $2.4 \pm 0.3 \%$ for $\delta^{13} \mathrm{C}$ and $\delta^{15} \mathrm{~N}$, respectively), and Model 2 based on the TEFs for captive bottlenose dolphins and killer whales as given by Caut et al. (2011) (1.26 $\pm 0.2 \%$ and $1.23 \pm 0.15 \%$ for $\delta^{13} \mathrm{C}$ and $\delta^{15} \mathrm{~N}$, respectively). Individual isotope ratios of porpoises $(n=52)$ were entered in the model, whereas for prey species $(\mathrm{n}=$ 49), means and standard deviations were used. The mixing model was run using default parameters (iterations: 500000 ; burn in: 50000 and thinning by: 15) without using concentration dependencies.

We used ANOSIM to examine variations in FA composition among groups. In addition, we used SIMPER to determine which FAs contributed to the differences between 2 sets of data. Factors used for the analysis were gender and age class, cause of death and blubber thickness. We used non-metric multi-dimensional scaling (MDS) to display groups according to some specific FAs. FAs are presented as percentage values. Analysis was performed on BrayCurtis similarity matrices calculated from untransformed FA data in PRIMER 5.

\section{RESULTS}

\section{Stomach contents}

More than 8000 individual prey remains (mainly otoliths) representing 13 species from 9 families were identified in the 14 stomachs analysed of harbour porpoises. In terms of occurrence $(\% O)$, Gobiidae, sprat, Ammoditydae, sand smelt Atherina presbyter and undetermined Gadidae dominated as prey, at 71, 50, 36, 29 and 29\%, respectively (Fig. 1a). In regards to percentage by number $(\% N)$, Gobiidae were the most important prey with $53 \%$, followed by Ammoditydae, sprat, herring and whiting, with 9, 8, 7 and $6 \%$, respectively (Fig. 1b). Similarly, Gobiidae was the main prey species with a contribution of $37 \%$ of the composition by weight $(\% W)$, followed by whiting $(22 \%)$ and sprat (14\%) (Fig. 1c).

\section{Stable isotopes and SIAR}

Stable isotope values measured in the muscle of harbour porpoises ranged from -18.5 to $-16.3 \%$ o for $\delta^{13} \mathrm{C}$, and from 13.5 to $18.4 \%$ or $\delta^{15} \mathrm{~N}$ (Table 1 ). For both males and females, $\delta^{13} \mathrm{C}$ values did not differ between juveniles and adults (ANOVA, p > 0.05). 

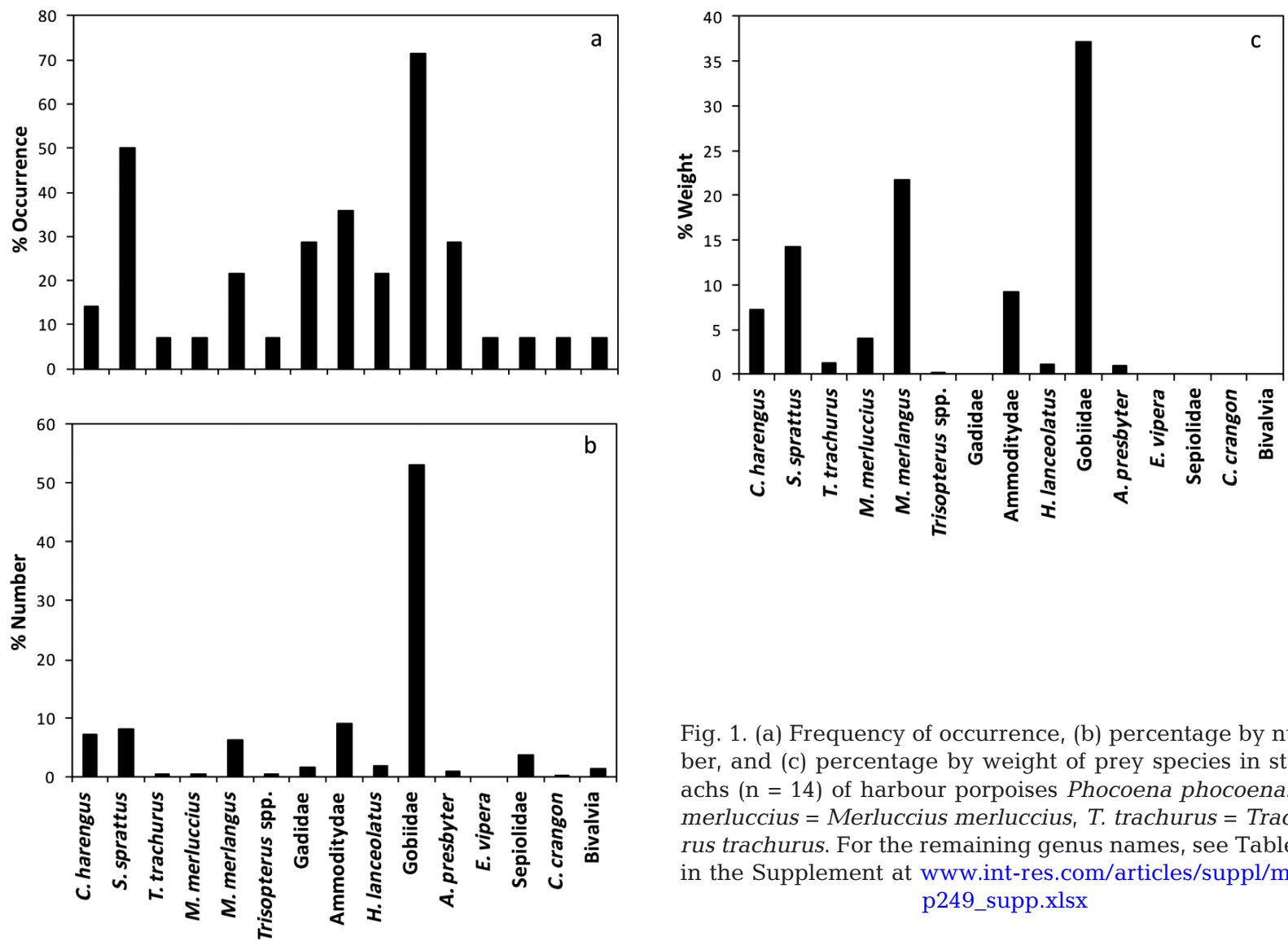

Fig. 1. (a) Frequency of occurrence, (b) percentage by number, and (c) percentage by weight of prey species in stomachs $(\mathrm{n}=14)$ of harbour porpoises Phocoena phocoena. $M$. merluccius $=$ Merluccius merluccius, $T$. trachurus $=$ Trachu rus trachurus. For the remaining genus names, see Table S1 in the Supplement at www.int-res.com/articles/suppl/m563 p249_supp.xlsx

Table 1. Size, and $\delta^{13} \mathrm{C}$ and $\delta^{15} \mathrm{~N}$ values in muscle of harbour porpoise Phocoena phocoena and selected fish species from the southern North Sea. n: number of individuals

\begin{tabular}{|c|c|c|c|c|c|c|c|}
\hline \multirow[b]{2}{*}{ Family/species } & \multirow[b]{2}{*}{$\mathrm{n}$} & \multicolumn{2}{|c|}{$\longrightarrow$ Size $(\mathrm{cm})-$} & \multicolumn{2}{|c|}{$-\delta^{13} \mathrm{C}(\%)-$} & \multicolumn{2}{|c|}{$-\delta^{15} \mathrm{~N}(\%)$} \\
\hline & & Mean $\pm \mathrm{SD}$ & $(\min , \max )$ & Mean \pm SD & (min, max) & Mean \pm SD & $(\min , \max )$ \\
\hline Harbour porpoise & 52 & $120 \pm 18$ & $(92,161)$ & $-17 \pm 0.5$ & $(-18.5,-16.3)$ & $15.8 \pm 1$ & $(13.5,18.4)$ \\
\hline Juvenile females & 15 & $115 \pm 10$ & $(98,133)$ & $-17.4 \pm 0.5$ & $(-18.2,-16.8)$ & $16.1 \pm 1.0$ & $(14.1,18.4)$ \\
\hline Juvenile males & 27 & $110 \pm 7$ & $(92,120)$ & $-17.3 \pm 0.5$ & $(-18.3,-16.3)$ & $15.9 \pm 1.1$ & $(13.8,18.0)$ \\
\hline Adult females & 7 & $156 \pm 6$ & $(145,161)$ & $-17.5 \pm 0.5$ & $(-18.5,-17.0)$ & $14.7 \pm 1.1$ & $(13.5,16.3)$ \\
\hline Adult males & 3 & $146 \pm 4$ & $(143,150)$ & $-17.3 \pm 0.5$ & $(-17.6,-16.9)$ & $15.4 \pm 0.6$ & $(14.7,15.9)$ \\
\hline \multicolumn{8}{|l|}{ Fish } \\
\hline \multicolumn{8}{|l|}{ Gadidae } \\
\hline Whiting Merlangius merlangus & 10 & $23 \pm 0.7$ & $(22,24.2)$ & $-16.9 \pm 0.3$ & $(-17.3,-16.3)$ & $16.3 \pm 0.4$ & $(15.6,17.0)$ \\
\hline Pouting Trisopterus luscus & 9 & $12 \pm 6.7$ & $(4.7,19.3)$ & $-17.8 \pm 0.6$ & $(-18.7,-16.7)$ & $14.5 \pm 1.1$ & $(13.7,17.0)$ \\
\hline \multicolumn{8}{|l|}{ Clupeidae } \\
\hline Herring Clupea harengus & 5 & $29 \pm 1$ & $(27.8,30)$ & $-18.5 \pm 0.5$ & $(-19.0,-17.6)$ & $10.8 \pm 0.7$ & $(9.9,11.4)$ \\
\hline Sprat Sprattus sprattus & 10 & $7.5 \pm 1.3$ & $(6.2,9.5)$ & $-17.7 \pm 0.7$ & $(-18.3,-16.2)$ & $13.5 \pm 0.7$ & $(12.4,14.5)$ \\
\hline Sardine Sardina pilchardus & 5 & $22.8 \pm 0.9$ & $(22,24)$ & $-18.5 \pm 0.4$ & $(-19.0,-18.0)$ & $12.4 \pm 0.7$ & $(11.4,13.2)$ \\
\hline \multicolumn{8}{|l|}{ Ammodytidae } \\
\hline Sandeel Hyperoplus lanceolatus & 5 & $24.3 \pm 5.5$ & $(20.3,32.6)$ & $-17.7 \pm 0.6$ & $(-18.4,-16.9)$ & $13.5 \pm 0.7$ & $(13.1,14.6)$ \\
\hline \multicolumn{8}{|l|}{ Gobiidae } \\
\hline Gobies & 5 & $6.2 \pm 0.6$ & $(5.6,7.3)$ & $-18.2 \pm 1.4$ & $(-20.3,-16.9)$ & $15.5 \pm 1.6$ & $(14.1,17.9)$ \\
\hline
\end{tabular}



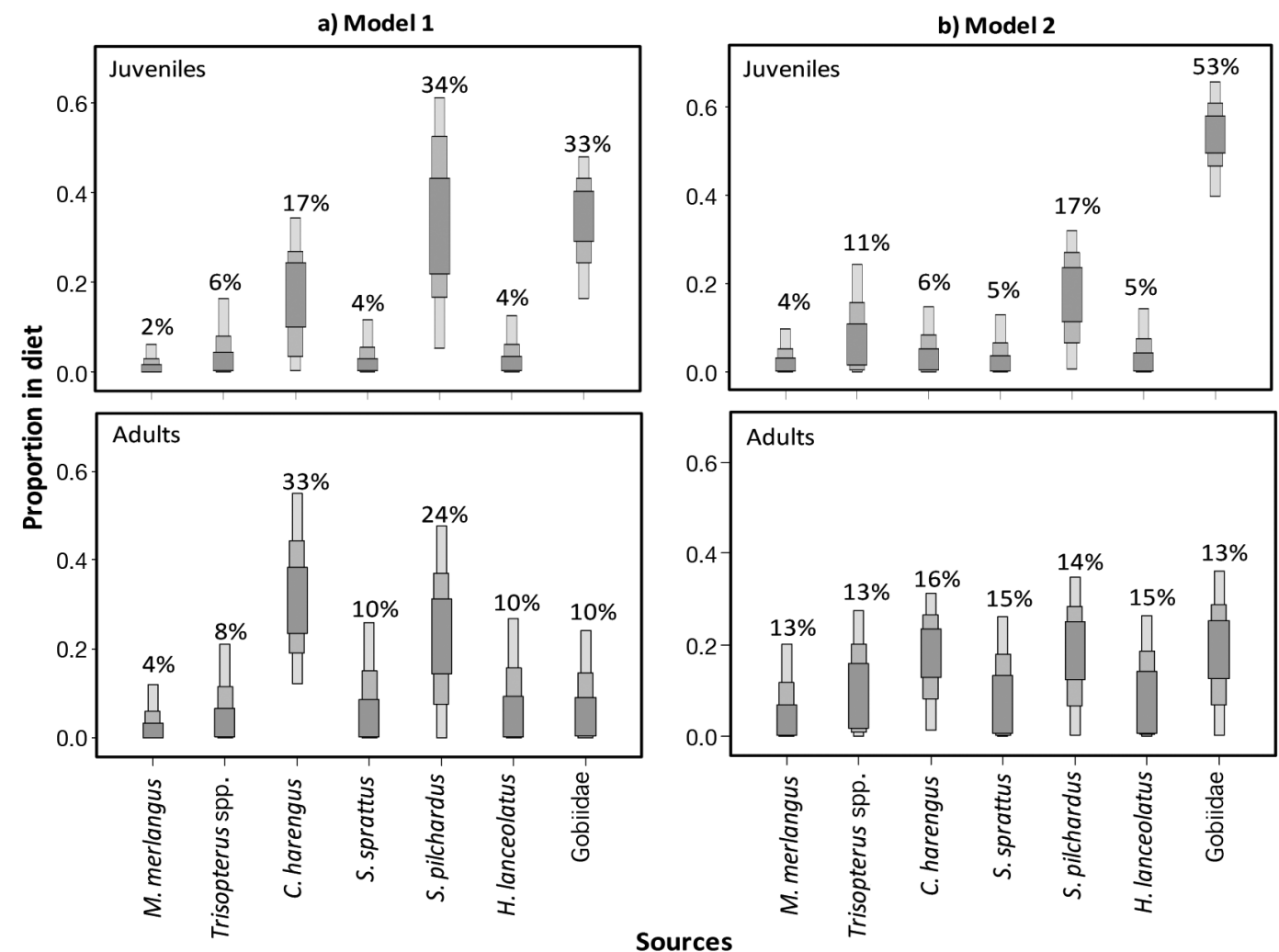

Sources

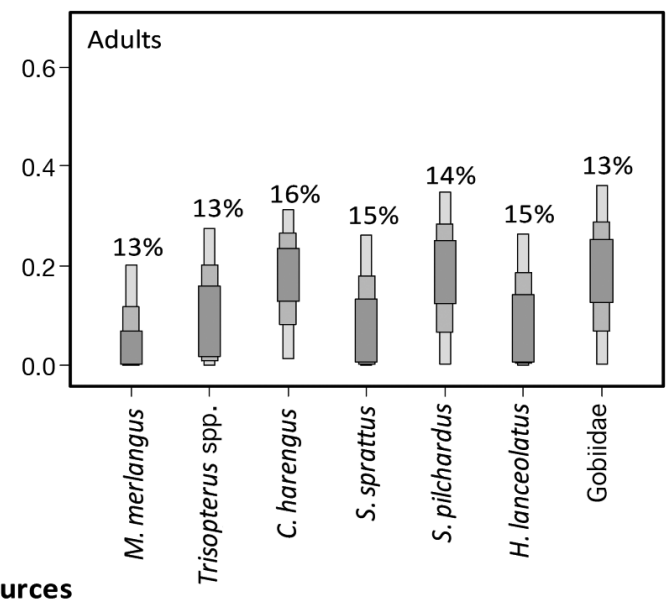

Fig. 2. Stable Isotope Analysis in R (SIAR) modeling: boxplots of estimated prey contributions in diet of harbour porpoises Phocoena phocoena (upper panels: juveniles, lower panels: adults). (a) Model 1 and (b) Model 2 (see 'Materials and methods' for model details). Credibility intervals $(\mathrm{CI})$ : $\mathrm{CI}_{95}$ : light grey; $\mathrm{CI}_{75}$ : medium grey and $\mathrm{CI}_{50}$ : dark grey. See Table 1 for genus names

However, $\delta^{15} \mathrm{~N}$ values were higher in juvenile females than in adult females (ANOVA, post hoc Tukey's test, $\mathrm{p}=0.03$ ), whereas comparing the other age classes, $\delta^{15} \mathrm{~N}$ values showed no significant differences. No significant differences were found in $\delta^{13} \mathrm{C}$ and $\delta^{15} \mathrm{~N}$ values in the muscle of porpoises stranded among years (ANOVA, $\mathrm{p}>0.05$ ). For the prey species, selected for SIAR model, $\delta^{13} \mathrm{C}$ values ranged between -20.3 and $-16.2 \%$ for Gobiidae and Sprattus sprattus, respectively. For $\delta^{15} \mathrm{~N}$, values ranged between 9.9 and $17.9 \%$ for Clupea harengus and Gobiidae, respectively (Table 1 ). The $\delta^{13} \mathrm{C}$ and $\delta^{15} \mathrm{~N}$ values were significantly different in the muscle of prey species (Kruskal-Wallis, $\mathrm{p}<0.001$ ).

The estimates from SIAR Model 1 showed that Sardina pilchardus and Gobiidae contributed the most to the diet of juvenile porpoises, at 34 and $33 \%$, respectively, whereas C. harengus and S. pilchardus contributed the most to the adults' diet, at 33 and $24 \%$, respectively (Fig. 2a). SIAR Model 2 estimated that Gobiidae contributed $53 \%$ to the diet of juvenile porpoises, while in the adult diet, the proportional contribution of each prey item was similar (range: 13-16\%) (Fig. 2b).

\section{FA composition}

A common spectrum of marine FAs was obtained for the harbour porpoises, with 40 compounds present in relative amounts $>0.1 \%$. FA profiles of the analysed porpoises were not significantly different between age classes and years of stranding (ANOSIM, p > 0.05). Within prey species, sandeel showed the highest amounts of polyunsaturated FAs (PUFAs) at $55.32 \pm 5.07 \%$, while herring exhibited the lowest amounts at $24.18 \pm 12.55 \%$ (Table S1 in the Supplement at www.int-res.com/articles/suppl/m563p249_ supp.xlsx). In contrast, herring had the highest amounts of monounsaturated FAs (MUFAs) (51.16 \pm $12.80 \%$ ), whereas sandeel had the lowest amounts $(11.78 \pm 2.88 \%)$ (Table S1).

Non-metric MDS of FA proportions from total FAs (Fig. 3) in the blubber of all harbour porpoises showed that according to some specific FAs, porpoises may be divided into 3 groups. Porpoises in which the proportion of the FA 16:107 is the highest $(>19 \%)$ are marked as Group a in Fig. 3; porpoises

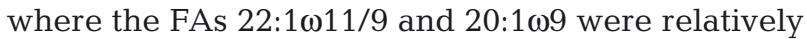
dominant (>3\%) are marked Group b; and those who 

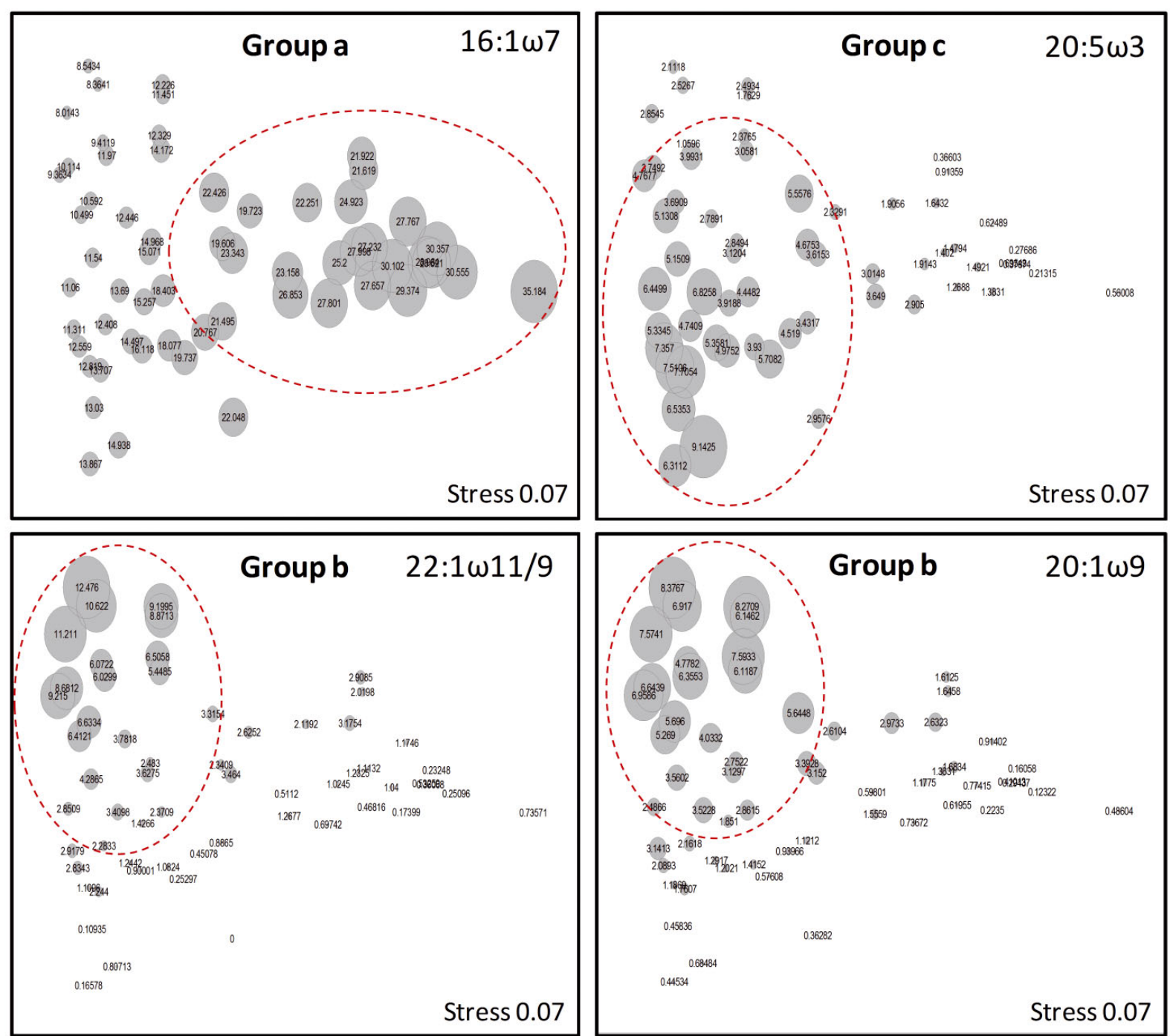

Fig. 3. Non-metric multi-dimensional scaling of fatty acid (FA) proportions (numerical data shown) from total FAs (\%) in harbour porpoise Phocoena phocoena (each grey ellipse represents an individual porpoise) blubber. Group a: the proportion of

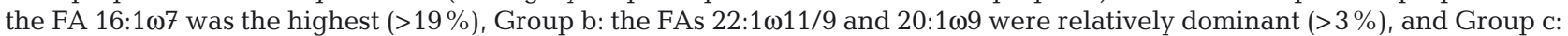
the proportion of the FA 20:5 13 was the highest (>5\%)

exhibited the largest proportion of 20:5 $03(>5 \%)$ are called Group c in Fig. 3.

\section{DISCUSSION}

\section{Comparison of dietary assessment methods}

Gobies, whiting and sprat primarily dominated the ingested biomass according to the stomach content analysis. Previous diet studies on harbour porpoises' stomachs in the North Sea found that these prey also contributed to the diet of this species (Leopold \& Camphuysen 2006, Haelters et al. 2012). Whiting and gobies are demersal and coastal species, which can explain their presence in the stomach content analysis and lead to the limitation of the method, since stranded individuals have stomach contents biased towards inshore prey species (Pierce \& Boyle 1991). The strength of stomach content analysis lies in the determination of prey size and number of individuals in the diet. It allows the identification of prey to species level, whereas stable isotope analysis often has less taxonomic resolution due to a lack of adequate separation between prey sources (an overlap in isotope signatures of similar prey species). However, even hard parts such as otoliths may be degraded by stomach gastric acids, leading to false negatives or to an over-representation with large and robust hard parts (Pierce \& Boyle 1991). 
The estimates from SIAR Model 1 showed that gobies, herring and sardine contributed the most to the diet of harbour porpoises, whereas Model 2 showed that only gobies contributed to the diet. The stable isotope results from the 2 models using different TEFs were quite different, suggesting some limitations to this approach in estimating proportions in the porpoise diet. These limitations include selecting the most appropriate TEFs and the absence of potential prey from the model. In fact, the TEFs used in the models are those of captive harp seals (Hobson et al. 1996) and captive bottlenose dolphins and killer whales (Caut et al. 2011); unfortunately, there were no available TEFs for harbour porpoises in the literature. Moreover, one should take into consideration the lack of sources; preferential and abundant prey could be missing and not included in our sampling data or we might have included a prey that harbour porpoises did not eat. In addition, if source signatures overlap considerably, the model can also have trouble distinguishing their contributions.

Variations in FA signatures may likely be due to differences in the diet of animals regardless of gender and age class. Elevated levels of 20:1 19 and $22: 1 \omega 11 / 9$ in the blubber of harbour porpoises from the southern North Sea reflected that some individuals may be feeding on zooplanktonivorous fish such as herring (Tocher 2003). Other FAs such as 16:1 107 markers of diatoms and present in high levels in the blubber of porpoises may be explained by indirect ingestion via herbivorous species with a diatom-

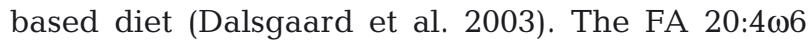
marker of benthic littoral algae (Dalsgaard et al. 2003) is present in elevated amounts in the muscle of prey benthic species such as gobies, whiting and pouting (Table $\mathrm{S} 1$ in the Supplement). However, these amounts were not found in porpoise blubber, even though according to the stomach content analysis, these 3 species contributed to the diet of porpoises. Gobies, whiting and pouting are benthic species, and their presence in the stomachs of porpoises may be explained by the last meal consumed before stranding (inshore), whereas the FA signatures reflect the diet of porpoises over a period of up to several months (Budge et al. 2006). It should be noted that, in our study, we only used FA profiles of the muscle of prey species, whereas porpoises consume the entire prey. In order to determine which specific species were present in the diet of harbour porpoises, a quantitative FA signature analysis (QFASA) needs to be applied (Iverson et al. 2004).

Combining techniques that integrate diet over days and weeks allowed the gaining of a more complete understanding of harbour porpoises' diet relative to stomach content. However, the interpretation of the results is limited by a lack of parameters which are necessary for each technique.

\section{Harbour porpoise distribution and prey species availability}

The diet of harbour porpoises stranded along the North Sea since the early 1990s to the present time primarily comprises 7 prey species: gobies, whiting, Trisopterus spp., sandeels, sprat, herring and sardine (Table 2). Besides the sardine, these species are among the most abundant fish and widely distributed in the North Sea (Daan et al. 1990, ICES 2013). Before the mid-1960s, clupeids constituted an impor-

Table 2. Harbour porpoise (Phocoena phocoena) diet inferred from stomach content analysis in the southern North Sea and adjacent areas. n: number of stomachs analysed

\begin{tabular}{|c|c|c|c|}
\hline Area (year of stranding) & $\mathrm{n}$ & Main prey & Reference \\
\hline Southern North Sea (2010-2013) & 14 & Gobies, whiting, sandeel & Present study \\
\hline Belgian coast (1997-2011) & 64 & Gobies, sandeels, whiting, Trisopterus sp. & Haelters et al. (2012) \\
\hline Dutch coast (2006) & 64 & $\begin{array}{l}\text { Gobies, sandeels, sprat, herring, whiting, } \\
\text { twait shad }\end{array}$ & $\begin{array}{l}\text { Leopold \& Camphuysen } \\
\text { (2006) }\end{array}$ \\
\hline $\begin{array}{l}\text { Northeast Atlantic French coast } \\
(1988-2003)\end{array}$ & 29 & Sardine, whiting, blue whiting, scad & Spitz et al. (2006) \\
\hline English Channel (1998-2003) & 7 & Pouting, gobies & De pierrepont et al. (2005) \\
\hline Scotland (1992-2003) & 188 & Whiting, sandeels, gadids, Trisopterus sp. & Santos et al. (2004) \\
\hline UK (1989-1994) & 100 & Gadids, sandeels, gobies & Martin (1996) \\
\hline Germany & 34 & Sandeels, sole & Benke \& Siebert (1996) \\
\hline Denmark, Sweden, Norway & 197 & Herring, gadids & Aerefjord et al. (1995) \\
\hline Germany & 36 & Sole, cod & Lick (1991) \\
\hline France & 8 & Blue whiting, scad, hake & Desportes (1985) \\
\hline Scotland (1959-1971) & 93 & Herring, sprat, whiting & Rae $(1965,1973)$ \\
\hline
\end{tabular}


tant part of the diet of harbour porpoises, but this has apparently changed after the collapse of the herring stock in the northeast Atlantic (Santos \& Pierce 2003). In recent years, herring and sardine are becoming more common again (Ifremer 2014), and their return could explain why clupeids, relatively fatty fish presenting an energetic prey in term of energy density (Spitz \& Jouma'a 2013), formed an important part of the diet of harbour porpoises in our study.

Gobies and Trisopterus spp. are important prey species in porpoises' diet (Table 2), but few data are available on their distribution and abundance. However, data from the International Bottom Trawl Survey (IBTS) in the North Sea showed that the relative abundance of Trisopterus spp. decreased since the year 2000, whereas gobies showed no clear temporal variations (Ifremer 2014). These species were accounted for in almost all previous studies (Table 2), and therefore they may be considered as traditional common prey in the diet of harbour porpoises in the North Sea. Herring, sprat, sandeel and whiting are important forage fish species in the North Sea, of economic interest and exploited by target fisheries (ICES 2013). It is well known that forage fish species display fluctuations in their distribution and abundance (Reid et al. 2001, Rijnsdorp et al. 2009). The relative abundance of herring, sprat and whiting in the North Sea from 1983 to 2010 showed no clear temporal variations, but that of the sandeel has undergone a pronounced decrease since the year 2001 (Ifremer 2014). Also, a decrease in the total landings of this species in the north and the centre of the North Sea has been noticeable. In many ecosystems, sandeel is a key prey fish linking trophic levels (Hain et al. 1995, Frederiksen et al. 2007). Since forage fish can exert bottom-up control on top predators, variability in the abundance of sandeels in response to fisheries pressure and climate change is likely to affect porpoise populations in the North Sea by increasing the likelihood of starvation (MacLeod et al. 2007) and changing their abundance and distribution (Reijnders 1992).

In the SIAR results of the present study, the sardine appeared to be a potential prey in the diet of harbour porpoises from the southern North Sea. This species did not figure in previous studies that analysed the stomachs of porpoises stranded in the North Sea (Santos et al. 2004, Haelters et al. 2012). Little information is known about the abundance of sardine in the North Sea; it is considered an occasional occupant and rarely occurs at a biomass large enough to attract fisheries exploitation (Engelhard et al. 2014). This small pelagic fish with more southern distribu- tion is an important commercial species in southern Europe. However, sardine distribution has increased in the North Sea over time. Since the mid-1990s, the re-invasion of the North Sea by sardines has been highlighted and has been associated with climate change (Beare et al. 2004a,b, Montero-Serra et al. 2015). Hence, sardines may be considered a 'new' potential prey species in the diet of porpoises in the North Sea, or it may be a 'backup' prey replacing the sandeel decline.

Results also suggest that porpoises may prey in offshore waters on pelagic shoaling species such as sardine in order to compensate for the decrease in abundance of demersal coastal species. It is necessary to find out whether the decline in one prey species could be counterbalanced by other species in the same area. It has been suggested that the lower survival or emigration of harbour porpoises in the central and southern North Sea in the late 1980s was either the result of food depletion or food lower in caloric content (Reijnders 1992). In fact, the foraging strategies and diet of harbour porpoises are guided by the quality of prey rather than the large quantity of food in order to meet their specific energy requirements (Spitz et al. 2012). Therefore, it is important to identify whether the quality of prey in the potentially new area of distribution of harbour porpoises can cover their energy requirements and consequently lead to the shift of this species towards the new area of distribution.

Acknowledgements. The French Stranding Network is thanked for the collection of harbour porpoise samples used in this study. The Grand Port Maritime de Dunkerque (France) is also thanked for the financial support of this study. We thank the Royal Belgian Institute of Natural Sciences for providing samples of harbour porpoises. The members of the RV 'Sepia' (INSU-CNRS) and the RV 'Thalassa' (Ifremer) are thanked for the collection of potential prey species. Florence Caurant and Sebastien Lefebvre are also thanked for their help in the stable isotope and SIAR interpretations. We thank Najet Thiney from the MNHN for her help in the FAs analysis and Khalef Rabhi for otolith analyses. C.M. was financially supported by a $\mathrm{PhD}$ fellowship from the National Council for Scientific Research (Lebanon) and Université du Littoral Côte d'Opale (France). We thank the reviewers for their helpful comments on an earlier version of this manuscript.

\section{LITERATURE CITED}

Aarefjord H, Bjorge AJ, Kinze CC, Lindstedt I (1995) Diet of the harbour porpoise (Phocoena phocoena) in Scandinavian waters. Rep Int Whal Comm Spec Issue 16:211-222

Beare DJ, Burns F, Greig A, Jones EG and others (2004a) Long-term increases in prevalence of North Sea fishes having southern biogeographic affinities. Mar Ecol Prog 
Ser 284:269-278

Benke H, Siebert U (1996) The current status of harbour porpoises (Phocoena phocoena) in German waters. International Whaling Commission, SC/47/SM49, Cambridge

Beare D, Burns F, Jones E, Peach K and others (2004b) An increase in the abundance of anchovies and sardines in the north-western North Sea since 1995. Glob Change Biol 10:1209-1213

* Bligh EG, Dyer WJ (1959) A rapid method of total lipid extraction and purification. Can J Biochem Physiol 37: 911-917

Bowen WD, Iverson S (2013) Methods of estimating marine mammal diets: a review of validation experiments and sources of bias and uncertainty. Mar Mamm Sci 29: 719-754

Budge SM, Iverson SJ, Koopman HN (2006) Studying trophic ecology in marine ecosystems using fatty acids: a primer in analysis and interpretation. Mar Mamm Sci 22:759-801

Camphuysen CJ (2004) The return of the harbour porpoise (Phocoena phocoena) in Dutch coastal waters. Lutra 54: 37-44

* Caut S, Laran S, Garcia-Hartmann E, Das K (2011) Stable isotopes of captive cetaceans (killer whales and bottlenose dolphins). J Exp Biol 214:538-545

*Daan N, Bromley PJ, Hislop JRG, Nielsen NA (1990) Ecology of North Sea fish. Neth J Sea Res 26:343-386

* Dalsgaard J, St. John M, Kattner G, Muller-Navarra D, Hagen W (2003) Fatty acid trophic markers in the pelagic marine environment. Adv Mar Biol 46:225-340

De Pierrepont JF, Dubois B, Desormonts S, Santos MB, Robin JP (2005) Stomach contents of English Channel cetaceans stranded on the coast of Normandy. J Mar Biol Assoc UK 85:1539-1546

Desportes G (1985) La nutrition des odontocetes en Atlantique nord-est (cotes Francaises - iles Feroe). PhD thesis, Université de Poitiers

Engelhard GH, Peck MA, Smout S, Rindorf A and others (2014) Forage fish, their fisheries, and their predators: who drives whom? ICES J Mar Sci 71:90-104

Frederiksen M, Furness RW, Wanless S (2007) Regional variation in the role of bottom-up and top-down processes in controlling sandeel abundance in the North Sea. Mar Ecol Prog Ser 337:279-286

Haelters J, Camphuysen CJ (2009) The harbour porpoise in the Southern North Sea: abundance, threats and research \& management proposals. Report for International Fund for Animal Welfare (IFAW). Royal Belgian Institute of Natural Sciences (RBINS/MUMM), Brussels, and Royal Netherlands Institute for Sea Research (NIOZ), Texel

Haelters J, Kerckhof F, Toussaint E, Jauniaux T, Degraer S (2012) The diet of harbour porpoises bycaught or washed ashore in Belgium, and relationship with relevant data from the strandings database. ASCOBANS North Sea Harbour Porpoise Conservation Plan, Bonn

Hain JHW, Ellis SL, Kennedy RD, Clapham PJ, Gray BK, Weinrich MT, Babb IG (1995) Apparent bottom feeding by humpback whales on Stellwagen Bank. Mar Mamm Sci 11:464-479

Kammond PS, Berggren P, Benke H, Borchers DL and others (2002) Abundance of harbour porpoise and other cetaceans in the North Sea and adjacent waters. J Appl Ecol 39:361-376

Hammond PS, Macleod K, Berggren P, Borchers DL and others (2013) Cetacean abundance and distribution in
European Atlantic shelf waters to inform conservation and management. Biol Conserv 164:107-122

Herr H, Fock HO, Siebert U (2009) Spatio-temporal associations between harbour porpoise Phocoena phocoena and specific fisheries in the German Bight. Biol Conserv 142: 2962-2972

* Hobson KA, Piatt JF, Pitocchielli J (1994) Using stable isotopes to determine seabird trophic relationships. J Anim Ecol 63:786-798

*Hobson KA, Schell DM, Renouf D, Elizabeth N (1996) Stable carbon and nitrogen isotopic fractionation between diet and tissues of captive seals: implications for dietary reconstructions involving marine mammals. Can J Fish Aquat Sci 53:528-533

* Hooker SK, Iverson SJ, Ostrom P, Smith SC (2001) Diet of northern bottlenose whales inferred from fatty-acid and stable-isotope analyses of biopsy samples. Can J Zool 79:1442-1454

ICES (2013) Report of the Working Group on the Assessment of Demersal Stocks in the North Sea and Skagerrak (WGNSSK), 24-30 April 2013, ICES Headquarters, Copenhagen. ICES CM 2013/ACOM:13

Ifremer (2014) Population and community indices derived from scientific surveys carried out by Ifremer. www. ifremer.fr/SIH-indices-campagnes/ (accessed 25 April 2014)

* Iverson SJ, Field C, Don Bowen W, Blanchard W (2004) Quantitative fatty acid signature analysis: a new method of estimating predator diets. Ecol Monogr 74:211-235

Jansen OE (2013) Fishing for food: feeding ecology of harbour porpoises Phocoena phocoena and white-beaked dolphins Lagenorhynchus albirostris in Dutch waters. $\mathrm{PhD}$ thesis, Wageningen University

Jauniaux T, Hartmann MG, Haelters J, Tavernier J, Coignoul F (2002) Echouage de mammifères marins: guide d'intervention et procédures d'autopsie. Ann Med Vet 146:261-276

Jauniaux T, Berguerie $\mathrm{H}$, Camphuysen $\mathrm{K}$, Daoust PY and others (2008) Causes of death of harbor porpoises (Phocoena phocoena) stranded on the continental coastline of the southern North Sea (Belgium, France, and Dutch coasts) between 1990 and 2007. ICES Annu Sci Conf, Halifax. ICES CM 2008/D:09

Koopman H, Iverson S, Gaskin D (1996) Stratification and age-related differences in blubber fatty acids of the male harbour porpoise (Phocoena phocoena). J Comp Physiol B 165:628-639

Kuiken T, Hartmann MG (1993) Proceedings of the first ECS workshop on cetacean pathology: dissection techniques and tissue sampling. Proc Eur Cetacean Soc, Leiden

Kassalle G, Gascuel D, Le Loc'h F, Lobry J and others (2012) An ecosystem approach for the assessment of fisheries impacts on marine top predators: the Bay of Biscay case study. ICES J Mar Sci 69:925-938

Leopold M, Camphuysen CJ (2006) Bruinvisstrandingen in Nederland in 2006: achtergronden, leeftijdsverdeling, sexratio, voedselkeuze en mogelijke oorzaken. IMARES Rep C083/06 and NIOZ Rep 2006-5. Wageningen IMARES and Koninklijk Nederlands Instituut voor Onderzoek der Zee (NIOZ), Texel

Leopold M, Van Damme CJG, Philippart CJM, Winter CJN (2001) Otoliths of North Sea fish. Fish identification key by means of otoliths and other hard parts. Expert Center for Taxonomic Identification, Amsterdam

Lick RR (1991) Parasites from the digestive tract and food 
analysis of harbour porpoise (Phocoena phocoena) from German waters. In: Evans PGH (ed) European research on cetaceans - 5. European Cetacean Society, Cambridge, p 65-68

MacLeod CD, Pierce GJ, Santos BM (2007) Starvation and sandeel consumption in harbour porpoises in the Scottish North Sea. Biol Lett 3:535-536

Martin AR (1996) The diet of harbour porpoises (Phocoena phocoena) in British waters. SC/47/SM48. International Whaling Commission, Cambridge

Meziane T, Tsuchiya M (2002) Organic matter in a subtropical mangrove-estuary subjected to wastewater discharge: origin and utilisation by two macrozoobenthic species. J Sea Res 47:1-11

Meziane T, Lee SY, Mfilinge PL, Shin PKS, Lam MHW, Tsuchiya M (2007) Inter-specific and geographical variations in the fatty acid composition of mangrove leaves: implications for using fatty acids as a taxonomic tool and tracers of organic matter. Mar Biol 150:1103-1113

Montero-Serra I, Edwards M, Genner MJ (2015) Warming shelf seas drive the subtropicalization of European pelagic fish communities. Glob Change Biol 21:144-153

Pierce GJ, Boyle PR (1991) A review of methods for diet analysis in piscivorous marine mammals. Oceanogr Mar Biol Annu Rev 29:409-486

Rae BB (1965) The food of the common porpoise (Phocoena phocoena). J Zool 146:114-122

Rae BB (1973) Additional notes on the food of the common porpoise (Phocoena phocoena). J Zool 169:127-131

R Development Core Team (2010) R: a language and environment for statistical computing. R Foundation for Statistical Computing, Vienna. www.R-project.org

Reid PC, Borges MF, Svendsen E (2001) A regime shift in the North Sea circa 1998 linked to changes in the North Sea horse mackerel fishery. Fish Res 50:163-171

Editorial responsibility: Scott Shaffer,

San Jose, California, USA
Reijnders PJ (1992) Harbour porpoises Phocoena phocoena in the North Sea: numerical responses to changes in environmental conditions. Neth J Aquat Ecol 26:75-85

* Rijnsdorp AD, Peck MA, Engelhard GH, Mollmann C, Pinnegar JK (2009) Resolving the effect of climate change on fish populations. ICES J Mar Sci 66:1570-1583

Santos MB, Pierce G (2003) The diet of harbour porpoise (Phocoena phocoena) in the northeast Atlantic. Oceanogr Mar Biol Annu Rev 41:355-390

Santos MB, Pierce GJ, Learmonth JA, Reid RJ and others (2004) Variability in the diet of harbour porpoises (Phocoena phocoena) in Scottish Waters 1992-2003. Mar Mamm Sci 20:1-27

Schomburg G (1987) Gaschromatographie: Grundlagen Praxis - Kapillartechnik, 2nd edn. Wiley-VCH, Weinheim

* Spitz J, Jouma'a J (2013) Variability in energy density of forage fishes from the Bay of Biscay (north-east Atlantic Ocean): reliability of functional grouping based on prey quality. J Fish Biol 82:2147-2152

Spitz J, Rousseau Y, Ridoux V (2006) Diet overlap between harbour porpoise and bottlenose dolphin: an argument in favour of interference competition for food? Estuar Coast Shelf Sci 70:259-270

Spitz J, Trites AW, Becquet V, Brind'Amour A, Cherel Y, Galois R, Ridoux V (2012) Cost of living dictates what whales, dolphins and porpoises eat: the importance of prey quality on predator foraging strategies. PLOS ONE 7:e50096

* Tieszen LL, Boutton TW, Tesdahl KG, Slade NA (1983) Fractionation and turnover of stable isotope in animal tissues: implication for delta ${ }^{13} \mathrm{C}$ analysis of diet. Oecologia 57: 32-37

* Tocher DR (2003) Metabolism and functions of lipids and fatty acids in teleost fish. Rev Fish Sci 11:107-184

Submitted: April 19, 2016; Accepted: October 25, 2016

Proofs received from author(s): December 20, 2016 